\title{
Nitrogen fertilisation in tropical pastures: what are the impacts of this
}

\section{practice?}

\author{
Antonio Leandro Chaves Gurgel ${ }^{1 *}$, Gelson dos Santos Difante ${ }^{1}$, Denise Baptaglin Montagner ${ }^{2}$, Alexandre \\ Romeiro de Araújo ${ }^{2}$, Alexandre Menezes Dias ${ }^{1}$, Juliana Caroline Santos Santana ${ }^{1}$, Jéssica Gomes \\ Rodrigues $^{3}$, Marislayne de Gusmão Pereira ${ }^{3}$
}

\author{
${ }^{1}$ Faculty of Veterinary Medicine and Animal Science, Federal University of Mato Grosso do Sul, Avenida Senador \\ Filinto Müller, 2,443, Campo Grande, CEP 79074-460, Mato Grosso do Sul, Brazil \\ ${ }^{2}$ Embrapa Beef Cattle, Campo Grande, Brazil, Av. Rádio Maia, 830 - Vila Popular, CEP. 79106-550, Campo Grande, \\ Mato Grosso do Sul, Brazil \\ ${ }^{3}$ Academic Unit Specialized in Agricultural Sciences, Federal University of Rio Grande do Norte, Rodovia RN 160, Km \\ 03, s/n - Distrito de Jundiaí, Macaíba - RN, CEP 59280-000, Rio Grande do Norte, Brazil
}

\section{*Corresponding author: antonioleandro09@gmail.com}

\begin{abstract}
It is estimated that approximately $47 \%$ of the world's ruminant meat and milk is produced in tropical and subtropical regions, with pasture comprising the main food base of these animals. Nitrogen fertilisation is an essential practice for the maintenance of pasture productivity, considering that a deficiency of this nutrient is a primary factor in triggering pasture degradation. In addition to directly influencing the photochemical and biochemical phases of photosynthesis, nitrogen stimulates enzyme activity and the synthesis of enzymes responsible for fixing $\mathrm{CO}_{2}$ (Rubisco in $\mathrm{C}_{3}$ plants and phosphoenolpyruvate carboxylase in $\mathrm{C}_{4}$ plants), thus increasing the efficiency of atmospheric $\mathrm{CO}_{2}$ capture. All of these physiological processes are easily observed macroscopically in the characteristics of forage plants. This review examines the impact of nitrogen fertilisation in tropical pastures on the main components of production systems (soil, plants and animals), describes the results obtained in different situations and highlights the most efficient ways of producing meat without environmental impacts.
\end{abstract}

Keywords: animal; environment; nitrogen; plant, production system; soil.

Abbreviations: IBGE_Brazilian Institute of Geography and Statistics, FAO_United Nations Food and Agriculture Organization, N_nitrogen, C/N_carbon-nitrogen ratio, SD_soil density, PR_penetration resistance, UA_450 kg animal unit, LAI_leaf area index.

\section{Introduction}

The Brazilian beef cattle industry has undergone major changes in recent years. From 1995 to 2016, the national cattle herd grew from 153.1 to 220.9 million head (30.8\%). One of the factors that has contributed to this advance is the opening of new agricultural frontiers, as evidenced by the growth in activity seen in the northern region of the country (Legal Amazon) in the last few years. The herd size in this region has grown faster than in other areas of the country; its proportion of the national herd size increased from $14 \%$ in 2010 to $22 \%$ in 2016 (IBGE, 2017).

The substantial increase in both cattle population and production efficiency seen in the last decade is a result of adopting and improving technological processes such as strategic supplementation, semi-confinement systems, multiple mixtures (Paula et al., 2011; Euclides et al., 2018) and breeding (Borba et al., 2016).

These practices have made it possible to reduce the production cycle; however, the particularity of livestock farming-that is, it is almost exclusively undertaken on pasture-is the predominant reason that beef cattle husbandry is a competitive activity worldwide. It is estimated that approximately $47 \%$ of the world's ruminant meat and milk originate from tropical and subtropical regions (FAO, 2013), and pasture comprises the main food base of these animals.

Brazil has a total pasture area of 158 million hectares (IBGE, 2017). In spite of the national herd size and all of the technological advances, Brazilian livestock production indices are still unsatisfactory, with lower values compared to its major competitors worldwide. This is mainly because neither pasture nor grazing management practices nor maintenance fertilisation have been widely adopted. An alternative approach to optimising forage production, and consequently improving livestock production indices, is to associate pasture and soil management strategies. Nitrogen (N) fertilisation, along with maintenance 
fertilisation, is essential to ensure pasture productivity (Liu et al., 2010; Świtek et al., 2019; Loide, 2019), and the low adoption of these tools is considered one of the main triggers of the degradation process. The influence of pasture management and $\mathrm{N}$ fertilisation on forage canopy characteristics and animal performance is well-known; investigating this association can therefore contribute to an understanding of every link in the pasture-based production system (soil, plants and animals).

This review examines the impact of $\mathrm{N}$ fertilisation of tropical pastures on the main components of production systems (soil, plants and animals), describes the results obtained in different situations and highlights the most efficient ways of producing meat without environmental impacts.

\section{Nitrogen dynamics}

Nitrogen is the most abundant element in the terrestrial atmosphere (70\%). It constitutes a molecule of importance for life on earth, since the element is required in larger amounts by the majority of plants and has numerous functions. Specifically, in the plant, $\mathrm{N}$ is one of the most important components of amino acids, proteins, nucleic acids and enzymes. In addition, it promotes plant growth and is responsible for their green pigmentation (Taiz and Zeiguer, 2006).

This nutrient flows through the system via a pathway called the ' $\mathrm{N}$ cycle', which is considered an open system, subject to inputs and outputs, within the pasture ecosystem (Vestgarden et al., 2004). Nitrogen enters the system mainly through atmospheric deposition ( $\mathrm{Li}$ et al., 2002), the biological fixation of atmospheric $\mathrm{N}$ gas $\left(\mathrm{N}_{2}\right)$ (Gaudin et al., 2014), chemical fertilisation (Loide, 2019) and recycling in the soil-plant-animal system (Arlauskienè et al., 2019).

Atmospheric deposition occurs when ammonia and other nitrogenous compounds (originating from soil, plants and the burning of petroleum) present in the atmosphere are incorporated into the soil through rainwater (Li et al., 2002). The quantity added by precipitation depends on proximity to animal management centres. Electrical discharge (lightning) can also convert atmospheric $\mathrm{N}_{2}$ into oxide and subsequently nitrate (Li et al., 2002).

Biological $\mathrm{N}$ fixation is performed by cyanobacterial and bacterial species capable of transforming $\mathrm{N}_{2}$ into ammonia $\left(\mathrm{NH}_{3}\right)$, which are hence termed ' $\mathrm{N}$ fixers'. This process is limited in $\mathrm{C}_{4}$ plants and is much more common in leguminous species (Gaudin et al., 2014). Nitrogen is also incorporated through recycling (Lassaletta et al., 2014); that is, some of the $\mathrm{N}$ extracted and assimilated by plant cells is consumed by the animal and returned to the system through its faeces and urine. Recycling also occurs through the deposition of organic matter originating from decaying forage plants (Arlauskienè et al., 2019).

The majority of the $\mathrm{N}$ present in most tropical soils is incorporated naturally into the soil's organic fraction. The mineralisation of this fraction represents an important source of $\mathrm{N}$ for forage grasses. $\mathrm{N}$ mineralisation and immobilisation are considered sub-cycles within the $\mathrm{N}$ cycle. These processes occur simultaneously, though antagonistically (Buysse et al., 2013).

Mineralisation is understood as the transformation of organic $\mathrm{N}$ into inorganic forms $\left(\mathrm{NH}_{4}^{+}\right.$or $\left.\mathrm{NH}_{3}\right)$. Because the process is intermediated by heterotrophic microorganisms in the soil, the conditions necessary for organic $\mathrm{N}$ mineralisation to occur are those which favour microorganism activity: a pH of 6 to 7, aerobic conditions, moisture between $50 \%$ and $70 \%$ of the soil's water-holding capacity and a temperature between $40^{\circ} \mathrm{C}$ and $60^{\circ} \mathrm{C}$ (Buysse et al., 2013). Immobilisation is defined as the transformation of inorganic $\mathrm{N}$ into its organic form. This process is performed by microorganisms that incorporate into their cells inorganic $\mathrm{N}$ available in the soil (Buysse et al., 2013). Because these two processes are simultaneous and antagonistic, the prevalence of one over another depends on the carbon-nitrogen $(\mathrm{C} / \mathrm{N})$ ratio in the soil organic matter (Buysse et al., 2013; Arlauskienè et al., 2019). An equilibrium condition, in which mineralisation is approximately equal to immobilisation, is achieved when the $\mathrm{C} / \mathrm{N}$ ratio in the organic matter is in the range of 20 to 30 . In this case, $N$ availability is not affected (Buysse et al., 2013).

In tropical-grass residues, which have a high $\mathrm{C} / \mathrm{N}$ ratio $(50)$, microorganisms rely on inorganic $\mathrm{N}$ in the soil to support their population growth, which is promoted by the availability of carbon in the soil (Buysse et al., 2013). Thus, in pasture-based animal production systems, soil $\mathrm{N}$ is mostly immobilised.

Nitrification and denitrification are other important processes that affect $\mathrm{N}$ dynamics in soil. These two reactions produce nitrogen oxides ( $\mathrm{NO}$ and $\mathrm{N}_{2} \mathrm{O}$ ). Nitrification produces relatively more $\mathrm{NO}$, while denitrification is the dominant process in $\mathrm{N}_{2} \mathrm{O}$ production (Kim et al., 2006), which is favoured under anaerobic soil conditions. Nitrification is favoured when $\mathrm{NH}_{4}{ }^{+}$is present in soil that is adequately aerated and is cycling $\mathrm{N}$ at high rates (Arlauskienè et al., 2019).

It is noteworthy that $\mathrm{N}$ originating from natural processes (atmospheric deposition, biological fixation of atmospheric $\mathrm{N}_{2}$ ) alone is insufficient to meet the nutritional needs of forage plants (Loide, 2019). For this reason, $\mathrm{N}$ is incorporated into the soil mainly via fertilisation with chemical sources.

In order for $\mathrm{N}$ found in the soil solution to be absorbed by the plant, it must make contact with the root system. This contact occurs mainly by mass flow, through the movement of ions in a mobile aqueous phase. After ion-root contact is established, absorption occurs passively; the element shifts from a region of higher concentration (the external solution) to a region of lower concentration (the cell wall, intercellular spaces and external surface of the plasmalemma [apparent free space]), with no energy expended by the plant cell. By contrast, during active absorption, the symplast is occupied, causing $\mathrm{N}$ to cross the plasmalemma's lipid barrier to reach the cytoplasm. For this, the cell must expend energy through respiration. The chemical source most widely used in pasture fertilisation is urea, since its high concentration of $\mathrm{N}$ (45\%) reduces transport and application costs. In addition, it is highly soluble, less corrosive and easy to manipulate (Yano et al., 2005). Nevertheless, if urea is not incorporated into the soil through rainwater or irrigation, $\mathrm{N}$ may be lost by volatilisation (Wang et al., 2016; Kaneko et al., 2019).

Nitrogen leaves the system mainly through erosion, removal by plants and animals, leaching, denitrification and ammonia volatilisation (Wang et al., 2016). As previously mentioned, some of this $\mathrm{N}$ returns to the pasture ecosystem; however, the total balance is negative due to irreversible outputs such as extraction by plants and subsequent assimilation into animal tissue, leaching losses and erosion (Lou et al., 2004). Therefore, to maintain pasture productivity and longevity, it is crucial to understand how forage plants respond to $\mathrm{N}$, as 
well as to identify management strategies that enable the most effective use of this nutrient.

\section{Effect of nitrogen on forage production}

Nitrogen is one of the main macroelements that limits plant growth in agrosystems. It is estimated that only $47 \%$ of the $\mathrm{N}$ added globally to soils is converted to and harvested in product form (Lassaletta et al., 2014). More than $50 \%$ of $\mathrm{N}$ is lost in the environment (Foyer et al., 2016), which leads to waste of forage resources, threats to biodiversity and bodies of water and increased emissions of polluting gases (Godinot et al., 2014). Given these facts, it is of paramount importance that current livestock systems adopt measures that utilise this nutrient with maximum efficiency.

In tropical regions, native pastures have been replaced with $\mathrm{C}_{4}$ forage grasses of African origins with great forage accumulation potential, especially those of the genera Brachiaria, Panicum and Cynodon (Pontes et al., 2016a; Euclides et al., 2017; Euclides et al., 2019). These grasses are highly responsive to $\mathrm{N}$ fertilisation when compared to those of temperate climates. In Europe, linear responses have been described in herbage production by temperate forage grasses following $\mathrm{N}$ fertilisation at doses of up to $300 \mathrm{~kg} \mathrm{ha}^{-1}$ $\mathrm{yr}^{-1}$ (Jarvis et al., 1995). In tropical grasses, linear responses have been observed following the application of annual $\mathrm{N}$ doses of 400 to $600 \mathrm{~kg} \mathrm{ha}^{-1}$ (Campos et al., 2016; Bernadi et al., 2018).

In addition to directly influencing the photochemical and biochemical phases of photosynthesis, $\mathrm{N}$ stimulates enzymatic activity and the synthesis of enzymes responsible for fixing $\mathrm{CO}_{2}$ (Rubisco in $\mathrm{C}_{3}$ plants and phosphoenolpyruvate carboxylase in $\mathrm{C}_{4}$ plants), thus improving atmospheric $\mathrm{CO}_{2}$ capture efficiency. In the photochemical phase, $\mathrm{N}$ acts on the synthesis of chlorophyll a, which is responsible for light capture, an essential process for subsequent stages of photosynthesis. In the biochemical phase, in turn, $\mathrm{N}$ is associated with protein/enzyme biosynthesis, which is linked to photosynthesis (Taiz and Zeiguer, 2006).

All of these physiological processes are easily observed macroscopically in the characteristics of forage plants. Higher $\mathrm{N}$ availability in the soil and, consequently, in plant cells, potentiates all these processes, in particular altering tiller leaf structure (Pontes et al., 2016b) (e.g., size, weight, appearance rate [Basso et al., 2010] and population density [Pitman, 2012]). Such changes result in higher herbage accumulation rates (Hoeschl et al., 2007; Lopes et al., 2013), herbage mass (Canto et al., 2013) and leaf mass (Pontes et al., 2016b). These factors ultimately provide a quantitative and qualitative increase in the herbage allowance (Liu et al., 2011; Fontes et al., 2014). Increased herbage intake-the variable most closely related to animal performance-has been observed in response to increased herbage allowances (Euclides et al., 2017).

Forage plants are highly responsive to $\mathrm{N}$, which can elicit a linear increase in yield up to a dose of $600 \mathrm{~kg} \mathrm{ha}^{-1}$ (Campos et al., 2016; Bernadi et al., 2018). As the $\mathrm{N}$ dose is increased, the opposite behaviour is seen in relation to fertilisation efficiency (Quaresma et al., 2011; Rowlings et al., 2016). A quadratic response may also be observed, whereby efficiency increases (Castagnara et al., 2011). In general, to achieve non-limiting $\mathrm{N}$ nutrition conditions, tropical grasses must be fertilised with $300 \mathrm{~kg}$ of $\mathrm{N} \mathrm{ha}^{-1} \mathrm{yr}^{-1}$ (Carvalho et al., 2013).
Nitrogen supply usually has little direct or indirect effect on the nutritional value of forage. Some studies have shown that increasing $\mathrm{N}$ fertiliser doses has little to no effect (Pitman, 2012), while others have observed an increase (Bartl et al., 2009; Pontes et al., 2016a) or reduction (Lima et al., 1999; Johnson et al., 2001) in the nutritional value of forage plants. These diverging results are linked to the plant's ability to absorb and accumulate $\mathrm{N}$ in its tissues (Pontes et al., 2016a; Pontes et al., 2016a) and the availability of the element in the soil (Luo et al., 2002).

\section{Effect of nitrogen on animal production}

In the presence of environmental resources, forage is produced (primary production), and this forage is consumed by the animal through grazing and converted into animal product (secondary production). This process is influenced by the animal's behavioural traits and by the nutritional and structural characteristics of the plant community (Carvalho et al., 2013). Nitrogen changes the plant community and leads to alterations in plant-animal interaction.

Stocking rates in tropical regions are generally higher or lower than pasture carrying capacity, which negatively affects forage production and animal performance (Carvalho et al., 2010). Intense or overly lenient grazing for long periods results in degradation, demonstrating the low sustainability of these systems (Lemaire et al., 2013; Euclides et al., 2019). To achieve maximum efficiency of primary and secondary production, it is essential to understand the complex interactions between plants and animals in intensive production systems.

Pasture productivity is the result of a combination of individual animal performance and stocking rate employed (Euclides et al., 2017). Individual performance, in turn, depends on the genetic potential of the animal, as well as the quality of the herbage and how it is supplied to the animal (Euclides et al., 2017; Euclides et al., 2018). Nitrogen fertilisation increases primary production (Bernadi et al., 2018) and changes grazing dynamics (Moreira et al., 2011), with a direct impact on individual secondary production and production per area (Pontes et al., 2016a).

Moreira et al. (2011), who investigated the production of cattle grazed continuously in Brachiaria decumbens pastures fertilised with $\mathrm{N}$, reported no effects of $\mathrm{N}$ fertilisation on the average daily gain of beef steers. However, when the $\mathrm{N}$ fertilisation dose was increased from 75 to $300 \mathrm{~kg} \mathrm{ha}^{-1}$, the stocking rate rose by $32 \%$ and $28 \%$, respectively, in the first and second years. A similar outcome was reported by Lupatini et al. (2013), who evaluated the performance of cattle in black-oat and ryegrass pastures fertilised with three $\mathrm{N}$ doses $\left(0,150\right.$ and $\left.300 \mathrm{~kg} \mathrm{ha}^{-1}\right)$ and found that stocking rate and live weight gain responded linearly to $\mathrm{N}$ levels.

Ribeiro et al. (2011) evaluated the effect of increasing $N$ doses $\left(75,150\right.$ and $225 \mathrm{~kg} \mathrm{ha}^{-1} \mathrm{~N}$ ) on Panicum maximum cv. Tanzania (Tanzania grass) pastures in a continuous grazing system and did not detect changes in individual cattle performance. However, the researchers observed that stocking rate and gain per area were highest at the $\mathrm{N}$ dose of $225 \mathrm{~kg} \mathrm{ha}^{-1}$. Other authors have also reported positive results in the performance of cattle in response to $\mathrm{N}$ fertilisation (Canto et al., 2009; Pinheiro et al., 2014). It should be stressed that, in all of the above-mentioned cases, pastures were managed under the same grazing-target condition: $50 \%$ reduction in canopy height as defined by $95 \%$ light interception, which potentiates the effect of $\mathrm{N}$. 


\section{Nitrogen and soil physics}

The presence in the soil of essential nutrients in balanced quantities (fertile soil), coupled with biological characteristics, is fundamental for the development of any agrosystem. However, for soil to be considered productive, not only must its chemistry and biology be taken into account, but also the physical characteristics that indicate its degree of compaction (Haynes \& Graham, 2004). Given the direct influence of animal trampling, the study of soil's physical attributes may be considered a key factor in the evaluation of soil quality in livestock systems (Stavi et al., 2012).

Soil density (SD) and the soil's mechanical resistance to penetration (penetration resistance, or PR) are the parameters most commonly used to evaluate soil's physical characteristics and degree of compaction (Torres et al., 2013). Soil structure is modified by animal trampling, which is influenced by interference with the pasture ecosystem (e.g., through pasture management and fertilisation) and time of year (Conte et al., 2011; Stavi et al., 2012). These changes affect primary and secondary production. When applying different management strategies in a production system, information about SD and PR is essential, since these variables are directly linked to pasture production and perenniality (Stavi et al., 2012).

Soil PR allows for inferences to be made about soil compaction at different depths. Among the physical variables of soil that can be evaluated, PR is admittedly the easiest to measure in terms of time and labour.

Furthermore, Chanasky and Naeth (1995) and Torres et al. (2013) reported that PR in livestock systems is more sensitive to animal trampling than other correlated variables and can thus be used to draw inferences about the soil compaction profile. A PR value of $2 \mathrm{MPa}$ has been established as a criterion for plant development (Lapen et al., 2004), while a PR of $3 \mathrm{MPa}$ has been used in forest soils (Zou et al., 2000). For soils planted with pasture, a PR of 2.5 $\mathrm{MPa}$ has been adopted as the limiting value for plant development (Leão et al., 2004).

SD is the property most widely used to quantify the physical quality of the soil of grazed pastures (Lanzanova et al., 2007; Fidalski et al., 2008; Torres et al., 2013). An SD of $1.40 \mathrm{~g} \mathrm{~cm}^{-3}$ in the soil of grazed pastures is considered restrictive to root growth and water infiltration (Souza et al., 2005). In such a system, PR and SD are closely related to animal trampling (Stavi et al., 2009). These effects are normally observed in the uppermost soil layers. During grazing, the pressure exerted by cattle weighing $500 \mathrm{~kg}$ can reach $0.50 \mathrm{MPa}$ (Proffitt et al., 1993).

Studies of pasture-based animal production systems always seek ways of increasing yield in order to optimise financial and environmental resources. Recurrent practices used to attain these goals include intensifying production systems through management practices, using supplementation strategically, choosing more productive cultivars and using maintenance and $\mathrm{N}$ fertilisation. Nitrogen application both intensifies the production system and increases the probabilities of PR and SD being altered.

Sarmento et al. (2008a) evaluated the PR of an Argisol cultivated with Panicum maximum Jacq. cv. IPR-86 Milênio under intermittent grazing conditions as a function of different $\mathrm{N}$ doses $\left(0,150,300\right.$ and $\left.450 \mathrm{~kg} \mathrm{ha}^{-1}\right)$. A higher PR was observed in soil fertilised with 300 and $450 \mathrm{~kg} \mathrm{ha}^{-1}$ of the element. The authors attributed this finding to the higher stocking rate observed at those doses (Sarmento et al.; 2008a). Likewise, Bertol et al. (2000) reported that SD in the 0 to $5 \mathrm{~cm}$ layer increased from 1.1 to $1.4 \mathrm{~kg} \mathrm{dm}^{-3}$ after the animal stocking rate was increased from 2.7 animals weighing $450 \mathrm{~kg}(\mathrm{AU})$ to $5 \mathrm{AU} \mathrm{ha}^{-1}$.

The larger herbage accumulation in the pasture resulting from increasing $\mathrm{N}$ doses (Hoeschl et al., 2007; Campos et al., 2016; Bernadi et al., 2018) is responsible for this increase in the stocking rate, which in turn increases trampling. The effects of trampling on PR and SD can be minimised by adopting a rest period, which allows normal soil conditions to be re-established. In this regard, Lanzanova et al. (2007) investigated the effect of two rest periods ( 14 and 28 days) without animal grazing on an intercropped pasture of black oat and ryegrass. When a 14-day rest period was used, a $36.4 \%$ increase in the ungrazed system was observed. When the pasture was rested for 28 days, the increase was only $30 \%$.

Gurgel (2019) examined the residual effect of $N$ fertilisation on the SD and PR of soil in pastures planted with Panicum maximum cv. Mombasa (Mombasa grass) and grazed by beef cattle. Higher SD and PR values were observed in the uppermost layers ( 0 to $10 \mathrm{~cm}$ and 10 to $20 \mathrm{~cm}$ ), regardless of the residual $\mathrm{N}$ dose. Although the stocking rate was 33\% higher at the highest residual dose $\left(300 \mathrm{~kg} \mathrm{ha}^{-1}\right)$ as compared to the lowest residual dose $\left(100 \mathrm{~kg} \mathrm{ha}^{-1}\right)$, the authors observed no effect of residual $\mathrm{N}$ concentration on the soil's physical characteristics. This response was attributed to the pasture rest period of 25 days, which was sufficient to decompress the soil. These results demonstrate that, even in intensive production systems, adequate pasture management allows the soil to re-establish physical conditions that are ideal for the forage plant's development.

\section{Effect of nitrogen on the root system}

Forage grasses have a fasciculate root, which plays a primary role in functions related to plant development such as structural support and nutrient absorption. Root development is directly affected by nutrient availability, moisture (Sarmento et al., 2008b), physical characteristics of the soil and pasture management (Beloni et al., 2016).

Plant shoot responses to $\mathrm{N}$ are widely known; however, the same is not true for the grass root system. Moreover, results have been conflicting. Giacomini et al. (2005) evaluated the root growth of Panicum maximum cv. Aruana (Aruana grass) and Tanzania grass when subjected to two N doses (150 and $300 \mathrm{~kg} \mathrm{ha}^{-1}$ ). A larger root mass was found in Tanzania grass when it was fertilised with $300 \mathrm{~kg} \mathrm{ha}^{-1} \mathrm{~N}$ compared to $150 \mathrm{~kg}$ $\mathrm{ha}^{-1}$; this difference was not observed for Aruana grass. A lack of response to fertilisation with increasing $N$ doses was also reported by Soares-Filho et al. (2013) for Tanzania grass and by Beloni et al. (2016) for Mombasa grass. On the other hand, Sarmento et al. (2008b) observed a quadratic effect for variables related to the root system of Panicum maximum cv. Milênio fertilised with four $\mathrm{N}$ doses $(0,150$, 300 and $450 \mathrm{~kg} \mathrm{ha}^{-1}$ ).

These inconsistent results have led to diverging discussions, which makes it difficult to understand root system dynamics as a function of $\mathrm{N}$ fertilisation. More sudden changes in the root system of forage grasses may be attributed to changes in pasture management practices that affect the leaf area index (LAI). When the LAI is substantially changed due to defoliation by animals, alterations are observed in the roots of forage plants (Bertol et al., 2000). 
Because forage grasses have a root type that cannot reach great depths, their roots are concentrated in the uppermost layers of the soil (Beloni et al., 2016). The greatest root density is limited to a depth of $20 \mathrm{~cm}$, where $50 \%$ of forage grass roots are found, regardless of pasture management practices or the chemical and physical characteristics of the soil (Sarmento et al., 2008b; Soares-Filho et al., 2013; Beloni et al., 2016; Barros et al., 2017).

\section{Conclusion}

Nitrogen fertilisation of tropical pastures promotes a considerable increase in primary and secondary production. Input of $\mathrm{N}$ into the system must be accompanied by other technologies that allow for maximum utilisation efficiency, such as pasture management practices that adjust for the stocking rate and suitable occupation and rest periods. In this way, SD and PR can be maintained at levels that allow for adequate water infiltration and root penetration into the soil. Pasture management is therefore a primary factor in controlling the physical characteristics of the soil and the root system of forage grasses, thus potentiating the positive effect of $\mathrm{N}$.

\section{References}

Arlauskienėa A, Cesevičienèb J, Velykisa A (2019) Improving mineral nitrogen control by combining catch crops, fertilisation, and straw management in a clay loam soil. Acta Agr Scand Sect B Soil PI. 69: 422-431.

Barros ACC, Almeida JCC, Carmargo Filho ST, Carvalho CAB, Campana LL, Morais LF (2017) Root dry matter mass and distribution of Florico grass under different grazing strategies. Pesquisa Agr Brasil. 52:1276-1285.

Basso KC, Cecato U, Lugão SMB, Gomes JAN, Barbero LM, Mourão GB (2010) Morfogênese e dinâmica do perfilhamento em pastos de Panicum maximum Jacq. cv. IPR-86 Milênio submetido a doses de nitrogênio. RBSPA. 11: 976-989.

Beloni T, Piotto VC, Mari GC, Pinheiro AA, Tormena, CA, Cecato $U$ (2016) Root system and resistance to penetration of Mombaça grass fertilized with nitrogen and irrigated. Semin-Cienc Agrar. 37: 3243-3252.

Bernardi A, Silva AWL, Baretta D (2018) Estudo metanalítico da resposta de gramíneas perenes de verão à adubação nitrogenada. Arq Bras Med Vet Zootec. 70: 545-553.

Bertol I, Almeida JA, Almeida EX, Kurtz, C (2000) Propriedades físicas do solo relacionadas a diferentes níveis de oferta de forragem de capim-elefante-anão cv. Mott. Pesquisa Agr Brasil. 35:1047-1054.

Borba LHF, Baldi F, Feitosa FLB, Silva LOC, Pereira ASC, Alencar MM (2016) Genetic correlations between visual slaughter conformation scores and growth and reproductive traits in Canchim cattle. Genet Mol Res. 15: 1-9.

Buysse P, Roisin C, Aubinet M (2013) Fifty years of contrasted residue management of an agricultural crop: impacts on the soil carbon budget and on soil heterotrophic respiration. Agr Ecosyst Environ. 167: 52-59.

Campos FP, Nicácio DRO, Sarmento P, Cruz MCP, Santos, TM, Faria AFG, Ferreira, ME, Conceição MRG, Lima CG (2016) Show more Chemical composition and in vitro ruminal digestibility of hand-plucked samples of Xaraés palisade grass fertilized with incremental levels of nitrogen. Anim Feed Sci Technol. 215: 1-12.
Canto MW, Hoeschl AR, Bona Filho A, Moraes A, Gasparino E (2013) Características do pasto e eficiência agronômica de nitrogênio em capim-tanzânia sob pastejo contínuo, adubado com doses de nitrogênio. Cienc Rural. 43: 682688.

Canto MWD, Bona Filho A, Moraes AD, Hoeschl AR, Gasparino E (2009) Animal production in Tanzania grass swards fertilized with nitrogen. Rev Bras Zootec. 38: 11761182.

Carvalho PCF (2013) Harry Stobbs Memorial Lecture: can grazing behavior support innovations in grassland management. Tropic Grassl - Forraj Tropical. 1:137-155.

Carvalho PCF, Anghinoni I, Moraes A, Souza ED, Sulc RM, Lang CR, Flores JPC, Lopes MLT, Silva JLS, Conte O, WESP LC, Levien R, Fontaneli RS, Bayer C (2010) Managing grazing animals to achieve nutrient cycling and soil improvement in no-till integrated systems. Nutr Cycl Agroecosyst. 88: 259-273.

Castagnara DD, Mesquita EE, Neres MA, Oliveira PSR, Deminicis BB, Bamberg R (2011) Valor nutricional e características estruturais de gramíneas tropicais sob adubação nitrogenada. Arch Zootec. 60: 232-933.

Chanasyk DS, Naeth MA (1995) Grazing impacts on bulk density and soil strength in the foothills fescue grasslands of alberta. Can J Soil Sci. 24: 551-557.

Conte O, Flores JPC, Cassol LC, Anghinoni I, Carvalho PCF, Levien R, Wesp CL (2011) Evolução de atributos físicos de solo em sistema de integração lavoura/pecuária. Pesquisa Agr Brasil. 46: 1301-1309.

Euclides VBP, Carpejani GC, Montagner DB, Nascimento Junior D, Barbosa RA, Difante GS (2017) Maintaining postgrazing sward height of Panicum maximum (cv. Mombaça) at $50 \mathrm{~cm}$ led to higher animal performance compared with post-grazing height of $30 \mathrm{~cm}$. Grass Forage Sci. 73: 174182.

Euclides VPB, Costa FP, Euclides Filho K, Montagner DB, Figueiredo GR (2018) Biological and economic performance of animal genetic groups under different diets. Biosci J. 34:1683-1692.

Euclides VPB, Montagner, DB, Macedo MCM, Araújo AR, Difante GS, Barbosa RA (2019) Grazing intensity affects forage accumulation and persistence of Marandu palisadegrass in the Brazilian savannah. Grass Forage Sci. 75:1-13.

FAO (2013) Mitigation of Greenhouse Gas Emissions in livestock production. A review of technical options for nonCO2 emissions. FAO Animal Production and Health paper 177. In: Gerber PJ, Henderson B, Makkar HPS. (eds). Rome, Italy: Food and Agriculture Organization of the United Nations, 226 pp.

Fidalski J, Tormena CT, Cecato U, Barbero LM, Lugão SMB, Costa MAT (2008) Qualidade física do solo em pastagem adubada e sob pastejo contínuo. Pesquisa Agr Brasil. 43: 1583-1590.

Fontes JGG, Fagundes JL, Backes AA, Barbosa LT, Cerqueira ESA, Silva LM, Morais JA, Vieira JS (2014) Herbage accumulation in Brachiaria brizantha cultivars submitted to defoliation intensities. Semin-Cienc Agrar. 35: 1425-1438.

Foyer CH, Lam H-M, Nguyen HT, Siddique KHM, Varshney RK, Colmer TD, Cowling W, Bramley $\mathrm{H}$, Moris TA, Hodgson JM (2016) Neglecting legumes has compromised human health and sustainable food production. Nat Plants. 2: 110. 
Gaudin ACM, Janovicek K, Martin RC, Deen W (2014) Approaches to optimizing nitrogen fertilization in a winter wheat-red clover (Trifolium pratense L.) relay cropping system. Field Crop Res. 155: 192-201.

Giacomini AA, Mattos WT, Mattos, HB, Werner JC, Cunha EA, Carvalho DD (2005) Crescimento de Raízes dos Capins Aruana e Tanzânia Submetidos a Duas Doses de Nitrogênio. Rev Bras Zootec. 34: 1109-1120.

Godinot O, Carof M, Vertes F, Leterme P (2014). SyNE: an improved indicator to assess nitrogen efficiency of farming. Agr Syst. 127: 41-52.

Gurgel ALC (2019) Interação solo-planta-animal em pastos de capim-mombaça sob efeito residual do nitrogênio. Natal: Federal University of Rio Grande do Norte, 2019. Dissertation. $56 \mathrm{f}$.

Haynes RJ, Graham MH (2004) Soil biology and biochemistry - a new direction for South African soil science? S Afr Tydskr Plant Grond. 21: 330-344.

Hoeschl AR, Canto MW, Bona Filho A, Moraes A (2007) Produção de forragem e perfilhamento em pastos de capim tanzânia-1 adubados com doses de nitrogênio. Scient Agrar. 8: 81-86.

IBGE - Instituto Brasileiro de Geografia e Estatística. Banco de dados agregados. 2017. Rio de Janeiro. Disponível em: <https://brasilemsintese.ibge.gov.br/agropecu

aria/efetivos-da-pecuaria.html/>. Acesso em: $02 \mathrm{dez}$. 2017.

Jarvis SC, Scholefield D, Pain BF (1995) Nitrogen Cycling in Grazing Systems. In: Bacon, P.E. (Ed.) Nitrogen Fertilization in the Environment. New York: Marcel Dekker Inc., 381$419 p$.

Johnson CR, Reiling BA, Mislevy P, Hall MB (2001) Effects of nitrogen fertilization and harvest date on yield, digestibility, fiber, and protein fractions of tropical grasses. J Anim Sci. 79: 2439-2448.

Kaneko FH, Ferreira JP, Leal AJF, Buzetti S, Reis AR, Arf O (2019) Ammonia volatilization in response to coated and conventional urea in maize crop field. Biosci J. 35:713-722.

Kim WK, Patterson PH (2006) Ammonium-Nitrogen Transformation and Nitrogen Retention in Broiler Manure Supplemented with a Soil Amendment Containing Nitrifying Bacteria. J Environ Sci Heal B. 41:121-133.

Lanzanova ME, Nicoloso RS, Lovato T, Eltz FLF, Amado TJC Reinert DJ (2007) Atributos físicos do solo em sistema de integração lavoura-pecuária sob plantio direto. Rev Bras Cienc Solo. 31: 131-1140.

Lapen DR, Topp GC, Gregorich EG, Curnoe, W.E (2004) Least limiting water range indicators of soil quality and corn production, Eastern Ontario, Canada. Soil Till Res. 78: 151170.

Lassaletta L, Billen G, Grizzetti B, Anglade J, Garnier J (2014) 50 year trends in nitrogen use efficiency of world cropping systems: the relationship between yield and nitrogen input to cropland. Environ Res Lett. 9: 1-9.

Leão TP, Silva AP, Macedo MC, Imhoff S, Euclides VPB (2004) Intervalo hídrico ótimo na avaliação de sistemas de pastejo contínuo e rotacionado. Rev Bras Cienc Solo. 28: 415-423.

Lemaire G, Franzluebbers A, Carvalho PCF, Dedieu B (2013) Integrated crop-livestock systems: strategies to achieve synergy between agricultural production and environmental quality. Agriculture. Agric Ecosyst Environ. 190: 4-8.

Li Y, Alva A, Calvert D, Banks D (2002) Atmospheric deposition of nitrogen in a high lightning intensity área. Commun. Soil Sci Plant Anal. 33: 1671-1677.
Lima GFC, Sollenberger LE, Kunkle WE, Moore JE, Hammond AC (1999) Nitrogen fertilization and supplementation effects on performance of beef heifers grazing limpograss. Crop Sci. 39: 1853-1858.

Liu E, Yan C, Mei X, He W, Bing SH, Ding L, Liu Q, Liu S, Fan T (2010) Long-term effect of chemical fertilizer, straw, and manure on soil chemical and biological properties in northwest China. Geoderma. 158: 173-180.

Liu K, Sollenberger LE, Silveira ML, Vendramini JMB, Newman YC (2011) Distribution of nutrients among soilplant pools in 'Tifton 85 ' bermudagrass pastures grazed at different intensities. Crop Sci. 51:1800-1807.

Loide V, (2019) The results of an NPK-fertilisation trial of long-term crop rotation on carbonaterich soil in Estonia. Acta Agr Scand Sect B Soil PI. 69: 1651-1913.

Lopes MN, Cândido MJD, Pompeu RCFF, Silva RG, Carvalho TCF, Sombra WA, Morais Neto LB, Peixoto MJA (2013) Biomass flow in massai grass fertilized with nitrogen under intermittent stocking grazing with sheep. Rev Bras Zootec. 42: 13-21.

Luo J, Lasegarampillai M, Bolan N, Donnison A (2004) Control of gaseous emissions of ammonia and hydrogen sulphide from cow manure by use of natural materials. $\mathrm{N}$ Zealand $\mathrm{J}$ Agricul Res. 2004. 47: 545-556.

Lupatini GC, Restle J, Vaz RZ, Valente AV, Roso C, Vaz FN (2013) Produção de bovinos de corte em pastagem de aveia preta e azevém submetida à adubação nitrogenada. Cienc Anim Bras. 14: 164-171.

Moreira, LM, Santos MER, Fonseca DM, Martuscello JÁ, Morais RV, Mistura C (2011) Produção animal em pastagem de capim-braquiária adubada com nitrogênio. Arq Bras Med Vet Zootec. 63:914-921.

Paula NF, Zervoudakis JT, Silva Cabral L, Carvalho DMG, Paulino, MF, Hatamotozervoudakis LK, Oliveira AA, Koscheck JFW (2011) Suplementação infrequente e fontes proteicas para recria de bovinos em pastejo no período seco: parâmetros nutricionais. Rev Bras Zootec. 40: 882891.

Pinheiro AA, Cecato U, Lins TOJA, Beloni T, Piotto VC, Ribeiro OL (2014) Produção e valor nutritivo da forragem, e desempenho de bovinos Nelore em pastagem de capimTanzânia adubado com nitrogênio ou consorciado com estilosantes Campo Grande. Semin-Cienc Agrar. 35: 2147 2158.

Pitman WD (2012) Bahiagrass (Paspalum notatum Flugge) management combining nitrogen fertilizer rate and defoliation frequency to enhance forage production efficiency. Grass Forage Sci. 68: 479-484.

Pontes LS, Baldissera TC, Giostri AF, Stafin G, Santos BRC, Carvalho PCF (2016b) Effects of nitrogen fertilization and cutting intensity on the agronomic performance of warmseason grasses. Grass Forage Sci. 72: 663-675.

Pontes LS; Giostri, AF, Baldissera TC, Barro, RS, Stafin G, Silva PV, Moletta, JL, Carvalho PCF (2016a) Interactive Effects of Trees and Nitrogen Supply on the Agronomic Characteristics of Warm-Climate Grasses. Agron J. 108: 111.

Proffitt APB, Bendotti S, Howell MR (1993) The efect of sheep trampling and grazing on soil fhysical propectics and pasture growth for Red-Brown carth. Aust J Agr Res. 44: 317-331.

Quaresma JPS, Almeida RG, Abreu JG (2011) Produção e composição bromatológica do capim-tifton 85 (Cynodon spp.) submetido a doses de nitrogênio. Acta Sci Animal Sci. 33: $145-150$. 
Ribeiro OL, Cecato U, Iwamato BS, Pinheiro A, Jobim CC, Damasceno JC (2011) Desempenho de bovinos em capimtanzânia adubado com nitrogênio ou consorciado com Estilosantes. RBSPA. 12: 275-285.

Rowlings DW, Scheer C, Liu S (2016) Annual nitrogen dynamics and urea fertilizer recoveries from a dairy pasture using $15 \mathrm{~N}$; effect of nitrification inhibitor DMPP and reduced application rates. Agric Ecosyst Environ. 216: 216-225.

Sarmento P, Rodrigues LRA, Cruz, Lugão SMB, Campos FP, Centurion JF, Ferreira, ME (2008a) Atributos químicos e físicos de um Argissolo cultivado com Panicum maximum Jacq. cv. IPR-86 Milênio, sob lotação rotacionada e adubado com nitrogênio. Rev Bras Cienc Solo. 32: 183-193.

Sarmento P, Rodrigues LRA, Cruz, Lugão SMB, Campos FP, Centurion JF, Ferreira, ME Oliveira RF (2008b) Sistema radicular do Panicum maximum Jacq. Cv.IPR-86 Milênio adubado com nitrogênio e submetido à lotação rotacionada. Rev Bras Zootec. 37: 27-34.

Soares Filho CV, Cecato U, Ribeiro OL (2013) Root system and root and stem base organic reserves of pasture Tanzania grass fertilizer with nitrogen under grazing. Semin-Cienc Agrar. 34:2415-2426.

Souza ED, Carneiro MAC, Paulino HB (2005) Atributos físicos de um neossolo quartzarênico e um latossolo vermelho sob diferentes sistemas de manejo. Pesquisa Agr Brasil. 40:1135-1139.

Stavi I, Lavee H, Ungar E, Sarah P (2012) Grazing-Induced Modification of a Semi-Arid Rangeland from a Two-Phase to a Three-Phase Mosaic Geo-Ecosystem. Arid Land Res Manag. 26: 79-83.
Świtek S, Takacs, V, Sawinska Z, Kosiada T, Tryjanowskia P (2019) Mineral nitrogen fertilisers remain a crucial factor even in the ecological intensification of agriculture. Acta Agr Scand Sect B Soil PI. 69(4): 311-316.

Taiz L, Zeiger E (2006) Fisiologia vegetal. 3rd. edn. Artmed, Porto Alegre. 722p.

Torres JLR, Rodrigues Junior DJ, Vieira DMS. (2013) Alterações nos atributos físicos do solo em função da irrigação e do pastejo rotacionado. Irriga. 18: 558-571.

Vestgarden LS, Nilsen P, Abrahamsen G (2004) Nitrogen cycling in pinus sylvestris stands exposed to different nitrogen inputs. Scand J For Res. 19: 38-47.

Wang H, Hu Z, Lu J, Liu X, Wen G, Blaylock A (2016) Estimation of Ammonia Volatilization from a Paddy Field after Application of Controlled-Release Urea Based on the Modified Jayaweera-Mikkelsen Model Combined with the Sherlock-Goh Model. Commun Soil Sci Plant Anal. 47: 1630-1643.

Yano GT, Takahashi, HW, Watanabe TS (2005) Avaliação de fontes de nitrogênio e épocas de aplicação em cobertura para o cultivo do trigo. Semin-Cienc Biológ Sau. 26:141148.

Zou C, Sands, R, Buchan G (2000) Least limiting water range: A potential indicator of physical quality of forest soils. Aust J Agr Res. 28: 947-958. 